\title{
The Impact of Government Income Transfers on the Brazilian Job Market
}

\author{
Emerson Marinho \\ Professor - Universidade Federal do Ceará (CAEN/UFC) \\ Endereço para contato: Av. da Universidade, 2.700 - $2^{\circ}$ andar - Benfica, Fortaleza - Ceará \\ CEP: 60020-181 - E-mail: emarinho@ufc.br
}

\section{Sérgio Mendes}

Secretaria Especial de Planejamento e Gestão/Tribunal de Justiça do Estado do Ceará Endereço para contato: General Afonso Albuquerque Lima, s/n - Cambeba, Fortaleza - Ceará CEP: 60822-325 - Email: sergio.filho@tjce.jus.br

Recebido em 09 de novembro de 2010. Aceito em 23 de maio de 2012.

\begin{abstract}
This paper intends to analyze the impact of transferences over the formal and informal labor supply from the family heads. For the analyze of the effects in scope of the entrance decisions in job market it was estimated a multinomial logit, while in the scope of the working time it was used a variation of the method of Durbin and McFadden (1984) for selection bias correction. It has verified that transferences have positive effect over the probabilities that the individual doesn't work and does informally work. However, this last one seems to be related to a substitution effect, once it has been observed a parallel negative effect over the probability to work on the formal sector. It has been obtained yet that the benefits negatively impacts on the offered hours by the family heads whether in the formal or non-formal sector, effect that has happened to be verified on the hours offering in formal sector of all individuals. On the other hand, as we consider the hours of working of those who are engaged in informal sector, it has obtained that income transferences perform not as a discourage issue but as a magnifier factor of worked hours.
\end{abstract}

\section{Keywords}

income transference, labor supply, selection bias

\section{Resumo}

Este artigo se propõe a analisar o impacto das transferências de renda governamentais sobre a oferta de trabalho formal e informal dos chefes de família no Brasil. Adicionalmente analisam-se os seus efeitos sobre as decisões dos indivíduos de entrar no mercado de trabalho. Para o primeiro objetivo estimou-se um logit multinomial, enquanto no âmbito da oferta de trabalho utilizou-se uma variação do método de Durbin e Mc Fadden (1984), que corrige o problema de viés de seleção. Dentre outros resultados obtidos, as transferências de renda contribuíram para o aumento da probabilidade de

\footnotetext{
- Os autores agradecem o apoio financeiro do CNPq para a realização deste trabalho.
} 
um chefe de família estar desempregado ou trabalhar no mercado informal. Por outro lado, diminui a sua chance de ficar empregado no setor formal caracterizando assim um efeito substituição. Com relação à oferta no mercado de trabalho, as transferências de renda governamentais parecem estar desincentivando o aumento de horas de trabalho tanto no setor formal quanto informal.

Palavras-Chave

transferência de renda, oferta de trabalho, viés de seleção

\section{Introduction}

This article aims to empirically assess the impact of government income money transfers on work-hour supply in the formal and informal job markets for heads of families in Brazil. Also here, there is an additional analysis of personal job market entrance choices.

Besides getting scientific interest, pro-poor fiscal policies based on income transfer programs also lead to numerous political and social discussions about these policies' probable adverse effects. Among which, there is the hypothesis that benefits might be an income source that leads individuals to lose interest in conventional labor. Another likely effect is the decrease in savings which is detrimental to credit, financing, and capital accumulation, thus affecting national economic growth. The likely reduction of working hours caused by government transfers might lead to higher social dependency and lessen the effects of economic growth on poverty rates. However, such effect is still controversial and there has been no consensus among authors dealing with the matter. Some of these authors are assessed in the next section of this work. In the latest decades, social protection programs have been created and spread as a method of fighting poverty and income inequalities. Be it in the form of coverage, be it in the form of benefits. Pinned to conditionalities that aim towards healthier and wealthier human capital, these programs despite differences in design, usually focus on needy social classes, and set out to fight poverty in short and long terms. Due to their large absorption of public budget resources, such programs have been the center of many theoretical and empirical analyses that aim to measure these programs' accuracy and efficiency, especially when it comes to poverty reduction and children's labor. Examples of such are the works of Hoffmann (2006), Cardoso and Souza (2004), Ferro and Kassouf (2005), Bourguignon et al. (2002) and Soares et al. (2006). 
Considering the relevance of the subject for the national politics and economy this article sets out to empirically assess how income transfers affect formal and informal labor supply for heads of families and these individuals' job market entry choices. In order to achieve these goals, two econometric models will be used. The first one is the logit multinomial model; its dependent variable is the "unemployed, informally employed or formally employed" category. The impact of income transfers on decisions about entering the job market is thoroughly investigated in this model which also controls determiners such as individual and socio-economic characteristics and family makeup. The second model aims to produce an equation of working hours supply for the formal and informal sectors of the Brazilian economy. It is an investigation on how government income transfers affect the working hours supply. Applied for this very purpose, a variation of the Durbin and McFadden (1984) method for the correction of selection bias based on multinomial logit models and also mentioned on Bourguignon et al. (2004). The database is extracted from the National Household Sampling Research (originally PNAD) of the year 2006 which includes heads of families.

As follows, besides this introduction, this article is segmented like this: the second section thoroughly describes the main federal income transfer programs in Brazil. Ensued by a brief outlook on the existing literature on impacts and collateral effects of these income transfer policies. In the third section, there is an introduction of the econometric model for the correction of the selection bias based on multinomial logit models. The fourth section deals with the assessment methodology that was applied, and also the definition and the construction of variables. Subsequently, in the fifth section, the results of the assessed models are analyzed. Finally, the last section exhibits the conclusions resulting from the article.

\section{Theoretical and Empirical Aspects of Income Transfer Programs}

As a way of complementing family income, the Bolsa-Família Program or PBF was created in late 2003 by a temporary government measure and was later turned into a federal law. The program was part of a wider project called Fome Zero (Portuguese for "Zero Hunger"). The PBF program presently helps more than 11 million

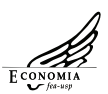


Brazilian families ${ }^{1}$ trying to overcome poverty (families whose monthly income ranges from $\mathrm{R} \$ 70,01$ to $\mathrm{R} \$ 140$ per person) and families dealing with extreme poverty, whose monthly income is up to $R \$$ 70 per person). The continuity of such benefits depends on how beneficiaries satisfy health and education standards set up by the government, such as school attendance, children's vaccination, prenatal and postnatal checkups. A family to be chosen to participate in the program must have monthly income of up to $R \$ 140,00$ per person and also must be listed on the CadÚnico List, which is the social programs' database. The main eligibility criterion being the per capita income declared by a family.

Besides PBF, Brazil has today two other big federal income transfer programs: The Continual Installment Benefit (a.k.a. BPC-Loas) and The Child Labor Eradication Program ( or PETI).The former is a monthly transfer of one minimum salary to severely disabled people of any age or senior citizens older than 65 . In both cases, in order to be eligible, one must have a per capita family income lower than one fourth of the minimum salary. The beneficiary of this program does not have to satisfy any further government standards in order to keep his or her recipient status. On the other hand, the PETI program was first implemented in 1996 for charcoal mill workers in the state of Mato Grosso do Sul. It was the very first federal income transfer program and originally aimed to rescue children and teenagers younger than 16 from unhealthy, hazardous or degrading jobs. It also aimed right from the start to improve these youngsters' education and citizenship levels through a series of coupled parallel measures. As one goal of the program, children and teenagers get the necessary conditions to remain in school. This is achieved due to socio-educational and socializing measures such as longer school hours.

Implementing programs of this kind has raised considerable interest from the national and international scientific community. Many studies have been conducted in order to assess the impact and adverse effects of such programs. According to Bourguignon et al. (2002), two kinds of approach can be applied to assess these programs. The first, the ex post approach, that is, the comparison between beneficiary and non-beneficiary performances, most probably controlling selection in the first or second group when random samples are not available. The second, the ex ante approach, which consists of a simulation of the program's effects based on a behavioral model of 
family members and the official rules involved in order to determine when an individual is eligible for the benefit or not. The first approach enables us to make an empirical and "real" assessment of the program's effects on the beneficiaries overall situation. The second approach aims to investigate through simulations, the program's impact variations caused by hypothetical design changes.

On an impact-on-child labor context, for instance, Ferro e Kassouf (2005) assessed the accomplishments of the Bolsa-Escola Program nationally using microdata from the 2004 PNAD survey. These authors applied two complementary strategies in order to assess the program's effects on a family's decision of allowing or not their kids between ages 6 and 15 into the job market, as well as the weekly hours these kids would work. For the first part, the researchers estimated a pondered probit with a dependent variable was 1 for a working kid and 0 for a non-working kid. A binary variable indicating participation or not in the program was included among the explanatory variables. For the second part, a work hour's equation was estimated, using the same probit explanatory variables. The researchers concluded that the policy was actually efficient in reducing the number of the kids' weekly work hours and also, that an additional benefit was removing around three hours of these kids' weekly work hours. However, these studies were not conclusive regarding the program's impact on a family decision of allowing or not a child into the job market.

Bourguignon et al. (2002), on the other hand, proposed a microsimulation method in order to assess ex ante, the impact of the Bolsa-Escola program on its two dimensions: children's occupational choice and national poverty reduction. The pre-established parameters used were based on a discreet multinomial choice model (logit multinomial) in order to know about the occupational decisions (to study and to work, just to study, just to work, not to study and not to work), the authors conducted simulations with various hypotheses about the income limit level for a family's eligibility and the transfer amount. The study revealed that the proportion of kids in the "studying and working" occupational category grows marginally and that around $40 \%$ of the children between 10 and 15 years old were responding to the program and such proportion grows to $60 \%$ amongst the poorer ones. Regarding the effects of the program for poverty reduction, the results were less significant. The Bolsa-Escola

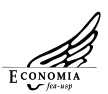


Program's original design reduced poverty in less than $1 \%$ and the Gini Index dropped to just less than 0,5\%. After that, the program managers realized that the target public was right but the poverty reduction effects would come later than expected.

Regarding collateral effects, more specifically the effects of these policies on the job market, Danzinger et al. (1981) brought to our attention that most income transfer programs, by offering income supplements without demanding any labor performances and also by reducing benefits to the top income levels, generate alterations in the inclination and in the curve position of a beneficiary's budget restriction. This way, the existence of such effects is actual if the Consumer Theory is applied, once an agent maximizes usefulness by the ability to choose income-leisure choices due to his or her budget restrictions. Danzinger et al. (1981) added that individuals could show different labor responses according to the work hours option restrictions imposed by labor laws or by employers and with cross-substitution effects involving job and wage choices of the rest of the family. ${ }^{1}$

When trying to detect the effects of the Bolsa-Família Program on the amount of work made available by mothers, Tavares (2008) used the Propensity Score Matching Method in order to estimate the Average Treatment Effect (ATE) and the Heckman Correction in order to assess the program's effect on the analysis of the endogenous selection problem. When comparing the results of the two estimates, it was seen that both ATE and The Heckman Correction suggested that the program's impact was a 10\% reduction of beneficiary mothers' work hours.

In a recent paper, Cavalcanti e Corrêa (2009) proposed a "matching" model with an endogenous destruction of jobs in order to ex ante analyze, the behavioral changes of job market agents after the onset of government income transfer programs. They concluded that the employed agent would keep working up to where the benefit found in the job market was at least equal to the benefit that he or she would get if in a domestic production situation. On the other hand, the unemployed agent as a beneficiary would keep looking for a job until the benefit of entering the job market was at least

1 The Cross-Substitution Effect happens when labor supply decisions and wage decisions are made collectively by family members, or indirectly, when taking the family budget as a reference. 
equal to the opportunity cost of the search. This way, it was found that the benefit sum affected job levels in a non-positive way, the authors came up with the hypothesis that by increasing the benefit, the job opportunity cost also increases, which makes some workers leave their jobs in order to do domestic production. Besides, the job search opportunity cost also rises, which makes some agents choose to leave the job market and work in domestic production. (Based on the premise that if they take a job, they will lose the benefit).

\section{The Correction of Selection Bias in Logit Multinomial Models}

Among the categories of sample selection, there is one that comes up when the dependent variable is observed only in a specific population subgroup. For instance, the work hour supply variable is visible only for individuals of strictly positive workload. In cases like these, selection bias is formed due to occasional truncation that happens when the regression variable $y_{1}$ depends on the result of another $y_{2}$ variable (possibly related to factors that are also associated with $y_{1}$ ), so that in the interest regression, the selection-determining variables get omitted.

In simpler cases, where the observability of the interest variable is determined by a binary variable, the endogenous selection problem can be easily solved by applying the procedure proposed by Heckman (1979), which consists of a regression of two stages on the system:

$$
\begin{aligned}
& y_{1}=x_{1} \beta_{1}+u_{1} \\
& y_{2}=1\left[x_{2} \delta_{2}+v_{2}>0\right]
\end{aligned}
$$

in which (la) is the equation that explains the interest variable as a vector of visible characteristics $x_{1}$ and of a $u_{1}$ disturbance, called structural equation; (lb) is the equation that explains the $y_{2}$ by $x_{2}$, the observable characteristic vector and by the latent characteristics $v_{2}$, called the selection equation; $\left(x_{1}, x_{2}\right)$ are always observable and the $y_{1}$ variable is only observable when $y_{2}=1$. 
According to Heckman (1979), consistent estimators of $\beta_{1}$ and $\gamma_{1}$ can be obtained by the regression of Ordinary Least Squares (OLS) of $y_{i 1}$ over $x_{i 1}$ and $\hat{\lambda} \equiv \lambda\left(x_{i 2}, \hat{\delta}_{2}\right)$, this last one being an estimator of $\delta_{2}$ obtained in a previous estimate of a probit for (1b), in which $\lambda(\cdot)$ is the Inverse Mills Ratio, that is, $\lambda\left(x_{2} \delta_{2}\right) \equiv \frac{\phi\left(x_{2} \delta_{2}\right)}{\Phi\left(x_{2} \delta_{2}\right)} 2$

In more complex models, where selection happens in a multinomial discrete choice process, according to Bourguignon et al. (2004), the configuration of the problem turns into this structure:

$$
\begin{aligned}
& y_{1}=x \beta_{1}+u_{1} \\
& y_{j}^{*}=z \gamma_{j}+\eta_{j,}, \quad \mathrm{j}=1,2, \ldots, \mathrm{M}
\end{aligned}
$$

where the $u_{1}$ disturbances satisfy $E\left(u_{1} / x, z\right)=0$ e $V\left(u_{1} / x, z\right)=\sigma^{2}$; $j$ represents a category variable that describes the agent's choice among the $\mathrm{M}$ alternatives based on the utilities named $y_{j}^{*}$; the $z$ and $x$ vectors have the variables that explain the alternatives and the interest variable ,respectively. Without loss of generalness, it is assumed that the $y_{1}$ variable is observable if and only if category $l$ is chosen, and this happens when:

$$
y_{1}^{*}>\max _{j \neq 1}\left(y_{j}^{*}\right)
$$

This condition equals to $\varepsilon_{1}<0$ if we define that:

$$
\varepsilon_{1}=\max _{j \neq 1}\left(y_{j}^{*}-y_{1}^{*}\right)=\max _{j \neq 1}\left(z \gamma_{j}+\eta_{j}-z \gamma_{1}-\eta_{1}\right)
$$

According to a demonstration by McFadden (1973), if it is assumed that the $\left(\eta_{j}\right)$ 's are independent and equally distributed with the Gumbel Distribution, this specification leads to the logit multinomial model, with a response probability as:

$$
P\left(\varepsilon_{1}<0 / z\right)=\frac{\exp \left(z \gamma_{1}\right)}{\sum_{j} \exp \left(z \gamma_{j}\right)}
$$

$2 \phi(\cdot)$ and $\Phi(\cdot)$ are respectively, the density function and the accumulated distribution function of the standard normal. 
This way, if one starts from the abovementioned expression, consistent estimates of $\left(\gamma_{j}\right)$ 's can be easily obtained through maximum likelihood. However, the problem still is, how to estimate the $\beta_{1}$ parameter vector, taking into account that the $u_{1}$ disturbances may not be independent of all $\left(\eta_{j}\right)$ 's, so that it inserts some sort of correlation between the explanatory variables and the disturbance term in the interest Equation (2a). Therefore, the $\beta_{1}$ estimates by OLS are consistent.

Generalizing the Heckman procedure (1979), Bourguignon et al. (2004) showed that the selection bias correction can be based on the $u_{1}$ conditional mean:

$$
E\left(u_{1} / \varepsilon_{1}<0, \Gamma\right)=\iint_{-\infty}^{0} \frac{u_{1} f\left(u_{1}, \varepsilon_{1} / \Gamma\right)}{P\left(\varepsilon_{1}<0 / \Gamma\right)} d \varepsilon_{1} d u_{1}=\lambda(\Gamma)
$$

where $\Gamma \equiv\left\{z \gamma_{1}, z \gamma_{2}, \ldots, z \gamma_{M}\right\}$ e $f\left(u_{1}, \varepsilon_{1} / \Gamma\right)$ is the coupled density condition of $u_{1}$ and $\varepsilon_{1}$.

They also concluded that, as the relations between the $\mathrm{M}$ components of $\Gamma$ and the $M$ corresponding probabilities can be inverted, there is one single $\mu$ function that can be replaced by $\lambda$ in such a way that:

$$
E\left(u_{1} / \varepsilon_{1}<0, \Gamma\right)=\mu\left(P_{1}, \ldots, P_{M}\right)
$$

Therefore, $\beta_{1}$ consistent estimates can be obtained in one of these two regressions:

$$
\begin{gathered}
y_{1}=x_{1} \beta_{1}+\mu\left(P_{1}, \ldots, P_{M}\right)+w_{1} \\
y_{1}=x_{1} \beta_{1}+\lambda(\Gamma)+w_{1}
\end{gathered}
$$

where $w_{1}$ is the residual that is on average independent of the regressors.

However, as the estimate of many parameters is needed when there is a big number of alternatives, restrictions on $\mu\left(P_{1}, \ldots, P_{M}\right)$ or equivalently on $\lambda(\Gamma)$, must be applied in order to keep the problem treatable. And when it comes to these restrictions, the proposed methods for bias correction available in literature differ from one another. 
In the method proposed by Durbin and McFadden (1984), the assumed hypothesis is linearity between disturbances which is expressed as terms of the $u_{1}$ mean, conditional to the $\left(\eta_{j}\right)$ 's by:

$$
E\left(u_{1} / \eta_{1}, \ldots, \eta_{M}\right)=\sigma \sum_{j=1, \ldots M} r_{j}\left(\eta_{j}-E\left(\eta_{j}\right)\right) \text {, with } \sum_{j=1 \ldots M} r_{j}=0
$$

This implies that:

$$
E\left(u_{1} / \eta_{1} \ldots \eta_{M}\right)=\sigma \sum_{j=2 \ldots M} r_{j}\left(\eta_{j}-\eta_{1}\right)
$$

Starting from this condition, and based on the logit multinomial model, Durbin and Mc Fadden (1984) obtained:

$$
E\left(\eta_{j}-\eta_{1} / y_{1}^{*}>\max \left(y_{s}^{*}\right), \Gamma\right)=\frac{P_{j} \ln \left(P_{j}\right)}{1-P_{j}}+\ln \left(P_{1}\right), \quad \forall j>1,
$$

and so they suggested that model that was described in (2a) and (2b) could be estimated through OLS through this equation:

$$
y_{1}=x_{1} \beta_{1}+\sigma \sum_{j=2 \ldots M} r_{j}\left(\frac{P_{j} \ln \left(P_{j}\right)}{1-P_{j}}+\ln \left(P_{1}\right)\right)+w_{1}
$$

When analyzing such procedure, Bourguignon et al. (2004) noticed that the hypothesis (3) determined a specific linearity between $u_{1}$ and the Gumbel distribution of the $\left(\eta_{j}\right)$ 's, and thus restricting the kind of distributions that were allowed for $u_{1}$. So, they suggested a variation of the hypothesis that made linear $u_{1}$ into a normal distribution group, for that would allow, in particular, that $u_{1}$ could also be normal with:

$$
E\left(u_{1} / \eta_{1} \ldots \eta_{M}\right)=\sigma \sum_{j=1 \ldots M} r_{j}^{*} \eta_{j}^{* 3}
$$

3 Please notice that (3) is a special case of (4) for $J\left(\eta_{j}\right)=\eta_{j}-E\left(\eta_{j}\right)$ and a normalization on the correlations, once Dubin e Mc Fadden (1984) normalize the errors, while (4) there's normalization due to the non-linear J transformation. 
where $r_{j}^{*}$ are the correlations between $u_{1}$ and the normal standardized variables $\eta_{j}^{*}=J\left(\eta_{j}\right)=\Phi^{-1}\left(G\left(\eta_{j}\right)\right), \mathrm{j}=1 \ldots \mathrm{M} .^{4}$

Besides, based on sample selection, the authors developed these conditional hopes:

$$
\begin{aligned}
& E\left(\eta_{1}^{*} / y_{1}^{*}>\underset{s \neq}{\max }\left(y_{s}^{*}\right), \Gamma\right)=m\left(P_{1}\right) \\
& E\left(\eta_{j}^{*} / y_{1}^{*}>\max \left(y_{s \neq}^{*}\right), \Gamma\right)=m\left(P_{j}\right) P_{j} /\left(P_{j}-1\right)
\end{aligned}
$$

where $m\left(P_{j}\right)=\int J\left(v-\log P_{j}\right) g(v) d v, \forall j$, and eventually concluded that after modifying the hypothesis, the regression equation (4) could be expressed as:

$$
y_{1}=x_{1} \beta_{1}+\sigma\left[r_{1}^{*} m\left(P_{1}\right)+\sum_{j=2 \ldots M} r_{j}^{*} m\left(P_{j}\right) \frac{P_{j}}{\left(P_{j}-1\right)}\right]+w_{1}
$$

According to Equation (5), the factors or variables that correct selection bias are defined as $m_{0}=m\left(P_{1}\right), m_{1}=m\left(P_{2}\right) \frac{P_{2}}{\left(P_{2}-1\right)}$ and $m_{2}=m\left(P_{3}\right) \frac{P_{3}}{\left(P_{3}-1\right)}$ in which $\sigma r_{1}^{*}, \sigma r_{2}^{*}, \sigma r_{3}^{*}, \ldots, \sigma r_{M}^{*}$ are their respective parameters to be defined.

Applying Monte-Carlo experiments in order to compare the performances of bias correction methods that are based on logit multinomial models (MLM), the authors also verified that, in most cases, the method proposed by Dubin e Mc Fadden (1984) is preferable to the most frequently used, Lee (1984), as well as to the semi-parametric alternative proposed by Dahl (2002). Experiments also showed that the Durbin e McFadden (1984) performance is very sensitive to the imposed normalization and that the suggested

\footnotetext{
4 Notice that for every $j$, Bourguignon et al. (2004) assumed that the expected values of $\mathrm{u}_{1}$ and $\eta_{j}$ are linearly related which is particularly true when the classic $u_{1}$ hypothesis is normal and $\left(u_{1}, \eta_{j}^{*}\right)$ is a bi-varied normal for any $j$ alternative.
} 
variable despite usually less robust than the original version, has better performance when the normalization hypothesis is tampered. Besides, it seems fit to capture intensively non-linear selection terms. For last, they concluded by using Monte-Carlo simulations that a selection bias correction based on the logit multinomial model provides good-enough corrections in the selection equation even when the hypothesis of the independence of irrelevant alternatives (IIA) is tampered.

\section{Methodology and Database}

In this section, there is a specification of the econometric models that will assess the impacts of government income transfers on the formal and informal labor supply in the Brazilian job market, controlling other determiners, the job market entrance decision as well as the decision about work hours offered by agents.

Table 1 - Variable Descriptions for the Multinomial Logit

\begin{tabular}{|c|c|c|}
\hline Dependent variable & Description & \\
\hline & & 0 Not to work \\
\hline \multirow[t]{2}{*}{ ocup } & Individual job decision & 1 To work in the informal market \\
\hline & & 2 To work in the formal market \\
\hline \multicolumn{3}{|c|}{ Explanatory variables for individual characteristics } \\
\hline age & years of age & numeric \\
\hline educ & years of education & numeric \\
\hline Dgender & gender dummy & 0 for females, 1 for males \\
\hline Drace & race dummy & 1 for white, 0 for other than white \\
\hline \multicolumn{3}{|c|}{ Explanatory variables for socio-economic characteristics } \\
\hline Dregion2 & country region dummy * & 1 North, 0 any other than north \\
\hline Dregion3 & country region dummy * & 1 Northeast, 0 any other than northeast \\
\hline Dregion4 & country region dummy * & 1 South, 0 any other than south \\
\hline Dregion5 & country region dummy * & 1 Midwest, 0 any other than midwest \\
\hline Dzurbanana & area dummy & 1 Urban zone, 0 any other than urban zone \\
\hline \multicolumn{3}{|c|}{ Explanatory variables for family characteristics } \\
\hline Dfamil2 & family makeup dummy ** & $\begin{array}{l}1 \text { Couples with all children younger than } 14,0 \text { other- } \\
\text { wise }\end{array}$ \\
\hline Dfamil3 & family makeup dummy ** & 1 Couples with all children at 14 or older, 0 otherwise \\
\hline Dfamil4 & family makeup dummy ** & 1 Couples with children younger, at;, or older than 14 \\
\hline Dfamil5 & family makeup dummy ** & 1 Mother with all children younger than 14,0 otherwise \\
\hline Dfamil6 & family makeup dummy ** & $\begin{array}{l}1 \text { Mother with all children at } 14 \text { or older than } 14,0 \\
\text { otherwise }\end{array}$ \\
\hline Dfamil7 & family makeup dummy ** & 1 Mother with children younger, at, or older than 14 \\
\hline Dfamil8 & family makeup dummy ** & 1 Other kinds of family, 0 otherwise \\
\hline
\end{tabular}

$\left(^{*}\right)$ Southeast Region as reference; $\left({ }^{* *}\right)$ Childless couple as reference.

Source: Data researched by the authors. 
For this purpose, a sample of individuals classified by the PNAD national survey, on the category "Reference Person of the Family" which otherwise means, heads of families. Initially a logit multinomial model is used, as described in Table 1 that will give the marginal effects on the answer probabilities $P(\mathrm{O}$ cup $=0), P(\mathrm{O}$ cup $=1)$ e $P($ Ocup $=2)$, whose estimated signs will allow to see how the explanatory variables, particularly the income transfer variable, affect the agents' decision about job market entry.

Then, after the answer probability estimates $P(\mathrm{O}$ cup $=0), P(\mathrm{O}$ cup = 1) e $P(\mathrm{Ocup}=2)$, the model (5) is used in order to estimate the equation of work hours supply. On this phase, the goal is to estimate the effect of government income transfers on individuals' work load, that is, on the hour-supply dependent variables in the informal sector (hours1) and the same in the formal sector (hours2), by using the methodology described in the previous pages, that is used for selection bias correction. The other control variables are the same that were used for the estimating the logit multinomial, except the family per capita income variable (rendper) which was replaced by the monthly income earned by an individual for all his work done (income).

The database that was used was taken from The National Survey of Household Samples (PNAD) conducted by The Brazilian Institute of Geography and Statistics (IBGE) in 2006, ${ }^{5}$ from which these variables were constructed: status of an individual in the job market (Ocup), income transfers from government to families (TRF), family per capita income (rendper), work hours in the informal sector (hours1) and work hours in the formal sector (hours2).

Regarding the TRF variables, the PNADs do not bring such information. The existence of additional supplements about the income transfers programs shown in PNAD's from 2004 until 2006 did not change the situation, as the supplementary form asked questions about the household and not about the specific individuals. Nor were these forms provided with specific questions about transfer income, which made it impossible to know which are the beneficiary families, for in a home, there might be more than just one family and income obtained through transfers remains unknown.

5 According to the new system of assessment adopted by IBGE in 2009 for the PNAD's from 2001 till 2008. 
This way, in order to calculate the amounts of family transfers, a filter was constructed for the entry "Savings Account Interest And Other Financial Investments And Other Income Sources" by selecting people whose family per capita income were equal or lower than half minimum wage valid for that year, (i.e., $\mathrm{R} \$ 175,00)$. It is supposed that the monetary value of this entry for the heads of families selected by this filter will show the income arriving from all government transfers. After all, it is expected that these individuals are not able to have any income originated in the financial market. Then, in order to obtain the Family Income Transfers (TRF), income transfers were matched with household units which were identified by their serial number and family control number, and then we added up the amounts gotten by every household member.

Regarding the individual job market status variable (Ocup), the data related to the entries "worked in a reference week" and "temporarily out of a reference week of remunerated work" were matched in order to determine the actually employed individuals. Among those who had done some work during a reference week, the ones to be regarded as formal job market workers those who ,under the entry "position in the occupation of the main job during the reference week" were also in the categories of military, officially employed, statutory government worker and officially employed house worker.

On the other hand, some individuals got categorized as informal market workers, namely those belonging to these segments: unofficially employed, unofficially employed house worker, self-employed individuals, self-supporting production workers, and people who were constructing dwellings for their own use.

The family per capita income (rendper) was created from entries like "monthly Family income for all the household units" and "number of household members ", whereas the hours1 e hours 2 variables were obtained after the construction of filters by the summation of the entries named " number of usual work hours per week on the main job in the reference week", "number of usual work hours per week on a secondary job" and "number of usual work hours per week in random jobs in the reference week". For last, monetary variables included in the rendper, TRF, and income regressions were deflated by the PNAD income deflator, constructed by the Research Institute of Applied Economics (IPEA) from data provided by the National 
Consumer Price Index - Restricted (INPC) of the IBGE statistics institute, and the General Price Index (IGP) of the Ministry of Labor based on the methodology suggested by Corseuil and Foguel (2002).

\section{Analysis of the Results}

\subsection{Results of the logit Multinomial Model}

Here, Table 2 shows the marginal effects obtained by using the logit multinomial ${ }^{6}$ model that was estimated according to the specifics described on Table 2. The marginal effect of government income transfers is positive for unemployed heads of families and for those working in the informal sector. For those in the formal sector, such effect is negative. This result seems to imply an adverse effect of income transfer programs on the job market. On one side, for heads of family, it increases the probability of remaining unemployed or getting work in the informal market, on the other side, it lessens his or her probability of remaining employed in the formal market.

\footnotetext{
6 The Hausman test was conducted in order to verify the irrelevant alternative independence hypothesis (IIA), however the test was not conclusive for the result showed variations according to which base was chosen for estimates. Long and Freese (2006) disapproved of this test exactly because it is prone to showing quite contradictory results. Likewise, Cheng and Long (2005) through Monte Carlo experiments, verified that both Hausman test and Small-Hsiao test showed little efficiency even when analyzing huge samples. Cheng and Long concluded that these tests are not of much use for assessing IIA Hypothesis violations. Besides, as Amemiya (1981) suggested, MLM works satisfactorily when alternatives are not close and similar, which seems to be the case of "Not to Work", "To Work in the Formal Sector" and "To Work in the Informal Sector".
} 
Table 2 - Marginal Effects for the Heads-of-family Sample

\begin{tabular}{|c|c|c|c|c|c|c|c|c|c|}
\hline & \multicolumn{3}{|c|}{$\mathrm{P}($ Ocup = 0$)$} & \multicolumn{3}{|c|}{$P($ Ocup = 1) } & \multicolumn{3}{|c|}{$\mathrm{P}($ Ocup = 2) } \\
\hline Variable & $d y / d x$ & $\begin{array}{l}\text { Standard } \\
\text { error }\end{array}$ & $P>|z|$ & $d y / d x$ & $\begin{array}{l}\text { Standard } \\
\text { error }\end{array}$ & $P>|z|$ & $d y / d x$ & $\begin{array}{l}\text { Standard } \\
\text { error }\end{array}$ & $P>|z|$ \\
\hline TRF & 0,0011 & 0,0000 & 0,000 & 0,0006 & 0,0001 & 0,000 & $-0,0016$ & 0,0001 & 0,000 \\
\hline Rendper & $-0,0001$ & 0,0000 & 0,000 & 0,0000 & 0,0000 & 0,000 & 0,0000 & 0,0000 & 0,000 \\
\hline age & 0,0135 & 0,0001 & 0,000 & $-0,0050$ & 0,0002 & 0,000 & $-0,0086$ & 0,0001 & 0,000 \\
\hline educ & $-0,0048$ & 0,0005 & 0,000 & $-0,0182$ & 0,0005 & 0,000 & 0,0230 & 0,0005 & 0,000 \\
\hline Dgender* & $-0,2983$ & 0,0057 & 0,000 & 0,1551 & 0,0054 & 0,000 & 0,1432 & 0,0044 & 0,000 \\
\hline Drace $^{\star}$ & $-0,0134$ & 0,0051 & 0,009 & $-0,0241$ & 0,0056 & 0,000 & 0,0376 & 0,0053 & 0,000 \\
\hline Dzurban* & 0,1146 & 0,0035 & 0,000 & $-0,2028$ & 0,0044 & 0,000 & 0,0882 & 0,0041 & 0,000 \\
\hline Dfamil2* & $-0,0778$ & 0,0053 & 0,000 & 0,0036 & 0,0057 & 0,531 & 0,0740 & 0,0054 & 0,000 \\
\hline Dfamil3* & $-0,0793$ & 0,0043 & 0,000 & 0,0127 & 0,0060 & 0,035 & 0,0667 & 0,0060 & 0,000 \\
\hline Dfamil4* & $-0,1584$ & 0,0044 & 0,000 & 0,0185 & 0,0070 & 0,008 & 0,1399 & 0,0072 & 0,000 \\
\hline Dfamil5* & 0,0904 & 0,0098 & 0,000 & $-0,0205$ & 0,0096 & 0,033 & $-0,0698$ & 0,0074 & 0,000 \\
\hline Dfamil6* & $-0,1105$ & 0,0053 & 0,000 & $-0,0208$ & 0,0096 & 0,031 & 0,1313 & 0,0101 & 0,000 \\
\hline Dfamil7* & $-0,1464$ & 0,0059 & 0,000 & 0,0562 & 0,1323 & 0,000 & 0,0902 & 0,1332 & 0,000 \\
\hline Dfamil8* & $-0,0152$ & 0,0054 & 0,005 & 0,0219 & 0,0061 & 0,000 & $-0,0066$ & 0,0057 & 0,242 \\
\hline Dregion2* & $-0,0311$ & 0,0046 & 0,000 & 0,1437 & 0,0052 & 0,000 & $-0,1126$ & 0,0038 & 0,000 \\
\hline Dregion3* & $-0,0008$ & 0,0040 & 0,824 & 0,0968 & 0,0044 & 0,000 & $-0,0959$ & 0,0036 & 0,000 \\
\hline region $4^{*}$ & $-0,0193$ & 0,0045 & 0,000 & 0,0311 & 0,0052 & 0,000 & $-0,0118$ & 0,0043 & 0,006 \\
\hline Dregion5* & $-0,0372$ & 0,0050 & 0,000 & 0,0623 & 0,0059 & 0,000 & $-0,0251$ & 0,0048 & 0,000 \\
\hline
\end{tabular}

$\left({ }^{*}\right)$ The dummy variables and $d y / d x$ represent a slight change of the dummy variable from 0 tol. Source: results that were obtained by the authors.

Another result is that the increase of the per capita income lessens the probability of a head of family of being unemployed. In an opposite way, it also increases his or her probability of being employed in the formal or informal sectors, despite the intensity of such probability, which is a very small one. The age of the head of family increases his or her chance of being unemployed by $1,35 \%$. But it also contributes by $0,049 \%$ e $8,6 \%$ for the diminishing of the probability of being employed in the informal or formal sector, respectively. This evidence shows what is usually debated in literature that finding a job is harder for older individuals. Regarding education, additional years of schooling will lessen by $0,48 \%$ and $1,82 \%$ the probability of a head of family of being unemployed or being employed in the informal sector, respectively. On the other hand, an increase by 2,3\% occurs for his or her chance of being formally employed. 
Male heads of family when compared to their female counterparts show less probability of being unemployed and more probability of being formally or informally employed. There is a decrease of $29,8 \%$ in the probability of a male head of family being unemployed and of him being informally employed it is $15,51 \%$ and $14,32 \%$ of being formally employed. Caucasian heads of family are less likely to be unemployed or be informally employed, when compared to other races. In the formal market, this result is reverted. There is a drop of $1,34 \%$ and $2,4 \%$, respectively, in the probabilities of being unemployed and informally employed. However, the formal sector shows an increase of $3,75 \%$.

These data suggest the existence of racial profiling in the Brazilian job market. Regarding family makeup, single mothers who are heads of family and with children under 14 are the ones with the biggest chance of being unemployed and the smallest chance to work in both formal and informal sectors. There is a $9,04 \%$ increase in the probability of being unemployed and decreases by 2,05\% and 6,98 \% of being informally and formally employed, respectively. This result clearly reveals the hardships found by mothers heading families with small children in adjusting a professional activity to their efforts in caring and educating their children.

The Brazilian regions show differences in job market occupations. When compared to the southeastern region, the north, the south and the Midwest regions have less probability of an individual of getting unemployed and bigger probabilities in the informal market. However, heads of family from the southeast have bigger chances of being employed in the formal sector, when compared to their counterparts in other regions.

\subsection{Results of the Estimate of Work Hour Supply}

The estimated results of the equation of work hours supply for heads of family, Equation (5), for the formal and informal sectors are shown on Table 3. Regarding the significance of the estimated coefficient, a 5\% significance level was given. The first obtained result is the evidence of an adverse incentive of income transfers on the job market. For both informal and formal sectors, the estimated 
signal of this variable is negative and statistically significant. That is, government income transfers seem to be working against the increase of work hour supply.

Table 3 - Second Stage Regressions for selection bias Correction of the Sample of Heads of Family

\begin{tabular}{|c|c|c|c|c|c|c|c|c|}
\hline \multirow[b]{2}{*}{ Variable } & \multicolumn{4}{|c|}{ hours1 } & \multicolumn{4}{|c|}{ hours2 } \\
\hline & Coef. & $\begin{array}{c}\text { Standard } \\
\text { error }\end{array}$ & $t$ & Value-p| & Coef. & Standard error & $t$ & Value-p \\
\hline TRF & $-0,0183$ & 0,0026 & $-7,17$ & 0,000 & $-0,0239$ & 0,0080 & $-3,00$ & 0,003 \\
\hline Income & 0,0039 & 0,0001 & 30,92 & 0,000 & 0,0008 & 0,0001 & 8,87 & 0,000 \\
\hline Age & $-0,1856$ & 0,0215 & $-8,62$ & 0,000 & $-0,1674$ & 0,0255 & $-6,57$ & 0,000 \\
\hline Education & 0,2313 & 0,0534 & 4,33 & 0,000 & 0,0464 & 0,1450 & 0,31 & 0,758 \\
\hline Dgender & 8,1013 & 0,5203 & 15,57 & 0,000 & 3,7265 & 0,4464 & 8,35 & 0,000 \\
\hline Drace & 0,1741 & 0,2586 & 0,67 & 0,501 & 0,3753 & 0,2713 & 1,38 & 0,167 \\
\hline Dzurban & 1,4515 & 0,4792 & 3,03 & 0,002 & 0,8608 & 1,0559 & 0,82 & 0,415 \\
\hline Dfamil2 & 1,4410 & 0,2586 & 5,37 & 0,000 & 1,2973 & 0,2906 & 4,46 & 0,000 \\
\hline Dfamil3 & 1,2350 & 0,4792 & 4,21 & 0,000 & 0,6732 & 0,2951 & 2,28 & 0,023 \\
\hline Dfamil4 & 2,7841 & 0,2686 & 6,83 & 0,000 & 1,6797 & 0,4536 & 3,70 & 0,000 \\
\hline Dfamil5 & $-2,3154$ & 0,2933 & $-5,05$ & 0,000 & $-0,3732$ & 0,4460 & $-0,84$ & 0,403 \\
\hline Dfamil6 & 1,0574 & 0,4076 & 3,35 & 0,001 & 1,3101 & 0,5563 & 2,35 & 0,019 \\
\hline Dfamil7 & $-0,5125$ & 0,4587 & $-0,85$ & 0,398 & 0,9164 & 0,4961 & 1,85 & 0,065 \\
\hline Dfamil8 & $-0,3572$ & 0,4497 & $-1,29$ & 0,197 & $-0,2919$ & 0,2338 & $-1,25$ & 0,212 \\
\hline Dregion2 & $-2,6164$ & 0,6051 & $-6,79$ & 0,000 & $-3,6490$ & 0,9298 & $-3,92$ & 0,000 \\
\hline Dregion3 & $-2,4901$ & 0,2766 & $-8,42$ & 0,000 & $-2,2579$ & 0,6884 & $-3,28$ & 0,001 \\
\hline Dregion4 & 0,3601 & 0,3852 & 1,47 & 0,142 & $-0,9299$ & 0,1989 & $-4,67$ & 0,000 \\
\hline Dregion5 & $-0,7283$ & 0,2965 & $-2,59$ & 0,010 & $-1,1305$ & 0,3229 & $-3,50$ & 0,000 \\
\hline$m_{0}$ & $-15,5978$ & 0,2454 & $-5,66$ & 0,000 & $-6,9832$ & 2,5677 & $-2,72$ & 0,007 \\
\hline$m_{1}$ & $-12,3781$ & 0,2809 & $-17,89$ & 0,000 & $-15,5961$ & 3,2571 & $-4,79$ & 0,000 \\
\hline$m_{2}$ & $-3,8233$ & 2,7720 & $-1,38$ & 0,168 & 2,1532 & 2,1982 & 0,98 & 0,327 \\
\hline const. & 42,9659 & 1,2286 & 34,97 & 0,000 & 37,6235 & 3,9166 & 9,61 & 0,000 \\
\hline \multicolumn{4}{|c|}{ Obs. number $=43.768 \quad F(21,43746)=278,64$} & \multicolumn{5}{|c|}{ Obs. number $=34.027 \mathrm{~F}(21,34005)=71,19$} \\
\hline \multicolumn{4}{|c|}{ Prob. $>F=0,000 R^{2}=0,1180 R_{\text {aj }}^{2}=0,1176$} & \multicolumn{5}{|c|}{ Prob. $>F=0,000 R^{2}=0,0421 \quad R_{\text {aj }}^{2}=0,0415$} \\
\hline
\end{tabular}

Source: results that were obtained by the authors.

Regarding the remaining determiners, the bigger a head of family's income, the bigger the work hours supply available for him or her in the formal and informal sectors. The estimated signal for this variable is positive and significant as seen on Table 3. Likewise, education which was measured by the average of school years, does contribute for the increase of the work hour supply in both sectors. On the other hand, age of heads of family has a negative impact on 
the work hour supply in both sectors of the job market. That is, older people tend to offer less work hours in whatever sector of the job market. Additionally, one can infer that urban area inhabitants or people who live in the southeast region offer comparatively more work hours than those residing in rural areas or other regions of Brazil. Regarding gender, the estimated coefficient of this variable's dummy suggests that men usually offer more work hours than women. Regarding family makeup dummies of heads of family, the characteristic of a mother being the head of family with children younger than 14 means less work hours when compared to the remaining categories.

The conclusion is, the selection bias correction was necessary, for in Equation (5), among the three variables $m_{0}, m_{1}$ and $m_{2}$ that spot the existence of non-observable variables, the first two variables were significant.

\section{Final Thoughts}

The main goal of the investigation conducted for this article seems to have been achieved. Government income transfers contributed to the increase of the probability of a head of family being unemployed and be working in the informal sector. However, this effect is negative when it comes to the formal sector. This result shows an adverse effect of income transfers programs on the job market. On one side, these transfers increase the probability of a head of family being unemployed or working in the informal market but on the other side, they lessen his or her chances of getting employed in the formal market. Possibly, a replacement effect might be happening, as individuals are encouraged to leave the formal sector for the informal one.

The per capita income decreases the probability of a head of family being unemployed and increases his or her chances of being formally or informally employed, despite the estimates of such effects are very small. In opposition to this, the age of a head of family contributes with a $1,35 \%$ increase to his or her chances of being unemployed, but also contributes with between $0,049 \%$ to $8,6 \%$ to the reduction of the probability of being employed in the informal and in the formal market, respectively. This evidence resonates with

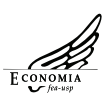


a topic usually debated in economics literature - Older individuals have a harder time finding a job. Education measured by an average of school years, contributes to a $0,48 \%$ decrease of the probability of a head of family being unemployed and a 1,82\% decrease of him or her be working in the informal sector. However, there is an increase by 2,3\% of the probability of one being employed in the formal sector. Men compared to women showed a smaller probability of being unemployed and a bigger probability of being employed in the formal or informal sector. The evidence of racial profiling seems to get confirmed. White head-of-family individuals do have fewer chances of being unemployed or employed in the informal market than individuals of other races do. This happens the other way round in the formal market.

Single head-of-family mothers who have children younger than 14 years old are the ones with bigger chances of getting unemployed and less probability of working in the formal and informal sectors. This result clearly shows the hard time that head-of-family mothers with little children have in harmonizing a professional job schedule to their motherly duties, such as general care and education of their children. Heads of family in the north, south and midwest regions have smaller probabilities of getting unemployed and the biggest probabilities in the informal market. However, heads of family in the southeast region have bigger chances of being employed in the formal sector than individuals in the other regions.

Regarding the analysis of hours offered in the job market, the evidence of an adverse effect caused by income transfers seems to be real. Either in the formal or informal sectors, government income transfers seem to be disincentivizing increases of work-hour supply. When it comes to other determiners, the bigger the income of a head of family, bigger is the amount of work hours that are supplied in the formal and informal sectors. Similarly, when education is analyzed and measured by the average of education years, it contributes to an increase of hours supplied in both sectors. Coming the opposite way, the age of these individuals negatively impacts on the hours supplied in the two sectors. Additionally, one can infer that urban area inhabitants or south region inhabitants in comparison, offer more work hours than those residing in rural areas and remaining regions of the country. Regarding gender, men offer more work hours than women. About family makeup of heads of family, the mother-with-children 
-younger-than-fourteen characteristic means less work hours offered, when compared to the other categories. In sum, government income transfers seem to show adverse effects on the Brazilian job market. They affect both the entrance decision and the work-hour supply.

\section{References}

AMEMIYA, T. Regression and ordered categorical variables. Journal of the Royal Statistical Society Series, B 46: 1-30, 1981.

BOURGUIGNON, F.; FERREIRA, F.H.G.; LEITE, P,G. Ex ante evaluation of conditional cash transfers programs: the case of bolsa escola.. The Willian Davidson Institute, University of Michigan, 2002 (Working Paper, n. 516). Disponível em: "http://www.wdi.umich.edu/files/Publications/ WorkingPapers/wp516.pdf” Último acesso em: 15/03/2010.

BOURGUIGNON, F; FOURNIER, M.; GURGAND, M. Selection bias corrections based on the the multinomial logit model: Monte-Carlo compararisons. Delta, 2004 (Working Paper, n. 2004-20). Disponível em: “http://www.delta.ens.fr/abstracts/wp200420.pdf”. Último acesso em: 15/03/2010.

CARDOSO, E.; SOUZA, A.P. The impact of income transfers on child labor and school attendance in Brazil. Vanderbilt University, 2004 (Working Paper, n. 04-W07). Disponível em: "http://www. vanderbilt.edu/Econ/wparchive/workpaper/vu04-w07.pdf'. Último acesso em: 15/03/2010.

CAVALCANTI, T.; CORREAA, M. Income transfers and labor market. IV Encontro CAEN-EPGE de Políticas Públicas e Crescimento Econômico, Jun.2009. Disponível em: "http:www.virtualbib. fgv.br/ocs/sbe/ebe09/paper/view/937/329”. Último acesso em: 15/03/2010.

CHENG, S.; LONG, J.S. Testing for IIA in the multinomial logit model. Sociological Methods \& Research, 35 (4): 583-600 (2007).

CORSEUIL, C.H.; FOGUEL, M. N. Uma sugestão de deflatores para rendas obtidas a partir de algumas pesquisas domiciliares do IBGE. Rio de Janeiro: IPEA, 2002 (Texto para discussão, n. 897). Disponível em: “http://www.ipea.gov.br/pub/bcmt/mt_019m.pdf”. Último acesso em: 15/03/2010.

DANZIGER, S.; HAVEMAN, R.; PLOTNICK, R. How income transfers programs affect work, savings, and the income distribution: a critical review. Journal of Economic Literature, 19: 975-1028, 1981.

FERNANDES, R.; PAZELLO, E.T. Avaliação das políticas sociais: incentivos adversos, focalização e impacto. In: LISBOA, M.; MENEZES-FILHO. N. A. Microeconomia e Sociedade no Brazil. Rio de Janeiro, 2001.

FERRO, A.R.; KASSOUF, A.L. Avaliação do impacto do programa bolsa-escola sobre o trabalho infantil no Brasil. Pesquisa e Planejamento Econômico. 35(3): 417-444, 2005.

FREESE, J.; LONG. J.S. Regression models for categorical dependent variables using stata. $2^{\mathrm{a}}$ ed. Texas: Stata Press Publications, 2006.

HECKMAN, J. The Common Structure of Statistical Models of Truncations, Sample Selection, and Limited Dependent Variables and a Simple Estimator for Such Models. In: Annals of Economic and Social Measurement, 5: 475-492, 1976.

HOFFMANN, R. Transferências de renda e a redução da desigualdade no Brasil e cinco regiões entre 1997 e 2004. Econômica, 8 (1): p.55-81, jun.2006.

SOARES, F.V.; SOARES, S; MEDEIROS, M.; OSÓRIO, R.G. Programas de transferências de renda no Brasil: impactos sobre a desigualdade e pobreza. Brasília: IPEA, 2006 (Texto para Discussão, n. 1.228). Disponível em: “http://www.anpec.org.br/encontro2006/artigos/A06A156.pdf”. Último acesso em: 15/03/2010. 
MCFADDEN, D. Conditional logit analysis of qualitative choice behavior. In: ZAREMBKA, P. (ed.). Frontiers of Econometrics. New York: Academic Press, 1973, pp. 105-142.

TAVARES, P.A. Efeito do programa bolsa família sobre a oferta de trabalho das mães. In: Anais do XXXVI Encontro Nacional de Economia. ANPEC, 2008. Disponível em: “http://www.anpec.org. br/encontro2008/artigos/200807211028050-.pdf”. Último acesso em: 15/03/2010.

WOOLDRIGDE, J.M. Econometric analysis of cross section and panel data. Cambridge, Massachusetts: The MIT Press, 2002. 